\title{
Avian influenza surveillance at the human-animal interface in Lebanon, 2017
}

Abeer Sirawan, ${ }^{1 *}$ Atika Berry, ${ }^{2 *}$ Rebecca Badra, ${ }^{*}$ Bassel El Bazzal, ${ }^{1}$ Mayssa Dabaja, ${ }^{1}$ Hussein Kataya, ${ }^{2}$ Ahmed Kandeil, ${ }^{4}$ Mokhtar R. Gomaa, ${ }^{4}$ Mohamed $\mathrm{Ali}^{4,5}$ and Ghazi Kayali ${ }^{3,6}$

${ }^{1}$ Lebanese Ministry of Agriculture, Bir Hassan, Jnah, Beirut, Lebanon. ${ }^{2}$ Lebanese Ministry of Public Health, Beirut, Lebanon. ${ }^{3}$ Human Link, Hazmieh, Lebanon. ${ }^{4}$ Center of Scientific Excellence for Influenza Viruses, National Research Centre, Giza, Egypt. ${ }^{5}$ Faculty of Biotechnology, October University of Modern Sciences and Arts, Cairo, Egypt. ${ }^{6}$ Department of Epidemiology, Human Genetics, and Environmental Sciences, University of Texas Health Sciences Center, Houston, United States of America (Correspondence to: G. Kayali: Eghazi@human-link.org). *First authors equally contributed.

\begin{abstract}
Background: Avian influenza viruses (AIVs) cause severe diseases in poultry and humans. In Lebanon, AIV H9N2 was detected in 2006 and 2010 and $\mathrm{H}_{5} \mathrm{~N} 1$ was detected in 2016.

Aim: To evaluate the current circulating AIVs in Lebanon at the human-animal interface.

Methods: A total of 1000 swabs were collected from poultry from 7 Lebanese governorates between March and June 2017. Swabs were screened for influenza infection. Haemagglutinin and neuraminidase AIV subtypes were determined for positive samples. Gene segments were cloned and sequenced. Blood was collected from 69 exposed individuals. Serological studies were performed to test sera for antibodies against AIV.

Results: In chickens, 0.6\% were positive for AIV H9N2. Sequences obtained clustered tightly with those of Israeli origin as well as Lebanese H9N2 viruses from 2010. All human samples tested negative.

Conclusion: We recommend regular surveillance for AIVs in poultry using a One Health approach.

Keywords avian influenza virus, endemic disease, epidemiology, virus surveillance, Lebanon

Citation: Sirawan A; Berry A; Badra R; El Bazzal B; Dabaja M; Kataya H; et al. Avian influenza surveillance at the human-animal interface in Lebanon, 2017. East Mediterr Health J. 2020;26(7):774-778. https://doi.org/10.26719/emhj.20.004

Received: 31/05/18; accepted: 21/01/19

Copyright (c) World Health Organization (WHO) 2020. Open Access. Some rights reserved. This work is available under the CC BY-NC-SA 3.0 IGO license (https://creativecommons.org/licenses/by-nc-sa/3.o/igo)
\end{abstract}

\section{Introduction}

Avian influenza (AI) is considered to be one of the most important viral diseases in the poultry industry. Both domesticated and wild birds can be infected with AI virus (AIV) (1). AIVs are divided into 16 haemagglutinin (HA) subtypes $\left(\mathrm{H} 1-\mathrm{H}_{16}\right)$ and 9 neuraminidase (NA) subtypes (N1-N9) (2). All influenza A subtypes have been isolated from wild bird species (3). However, highly pathogenic AI (HPAI) has been restricted to $\mathrm{H}_{5}$ and $\mathrm{H}_{7}$ subtypes in susceptible bird species (4), although not all $\mathrm{H}_{5}$ and $\mathrm{H} 7$ viruses are highly pathogenic. AIVs of all HA subtypes circulate in wild birds mostly as lowly pathogenic AI (LPAI) with few or no clinical signs (5).

Spillover from wild birds to poultry is not uncommon (6). The first AI case was isolated from poultry in 1878 in Italy (7). Since then, AI has been expanding worldwide in poultry. The occurrence and spread of LPAI or HPAI viruses in poultry vary depending on the levels of biosecurity and concentration of poultry in outbreaks or the emergence of HPAI virus (1).

Several human infections with avian influenza A viruses, including $\mathrm{H}_{5} \mathrm{~N}_{1}, \mathrm{H}_{9} \mathrm{~N}_{2}, \mathrm{H}_{7} \mathrm{~N}_{3}, \mathrm{H}_{7} \mathrm{~N}_{7}, \mathrm{H}_{7} \mathrm{~N}_{9}$ and $\mathrm{H} 10 \mathrm{~N} 8$, have been reported among poultry-exposed persons in several countries, with Egypt reporting the highest number of $\mathrm{H}_{5} \mathrm{~N} 1$ infections and China the highest number of $\mathrm{H} 7 \mathrm{~N} 9$ infections (8-13). Therefore, avian to human transmission has become an important public health issue. The spread of AIV from East Asia to the Middle East, Europe and Africa has raised the alarm that an influenza pandemic may be imminent (14). The burden of influenza in middle eastern countries is now of considerable concern. This agrees with the World Health Organization (WHO) alerts highlighting a major public health threat due to this adaptable virus that is capable of escaping vaccines or producing novel viral strains through antigenic drift or shift (15-17). Several middle eastern countries have reported human infections with AIV, including Egypt, Iraq, Djibouti and Pakistan (18). This pandemic potential has emphasized the importance of intensive surveillance and control measures at the human-animal interface.

In Lebanon, an $\mathrm{H}_{9} \mathrm{~N} 2$ outbreak occurred in 2006 in chickens in different provinces, leading to a remarkable drop in egg production. In 2010, $\mathrm{H}_{4}$ and $\mathrm{H} 11$ antibodies were detected in backyard growers from Bekaa and South Lebanon Governorates respectively (19). An outbreak of $\mathrm{H}_{5} \mathrm{~N} 1 \mathrm{HPAI}$ was first described in Lebanon in April 2016, in a farm in Baalbek in East Lebanon, leading to high mortality among chickens (20) that required the intervention of the Lebanese Ministry of Agriculture for monitoring and controlling. Culling of sick birds, decontamination of infected farms, and surveillance within the vicinity of infected farms were applied and the outbreak was resolved in June 2016 (21). H9N2 influenza vaccines have been licensed and used in all Lebanese 
farms. However, $\mathrm{H}_{5}$ and $\mathrm{H}_{7}$ vaccines are not licensed by the Lebanese Ministry of Agriculture.

To identify the current circulating AIV at the humananimal interface in Lebanon, we conducted a nationwide, cross-sectional survey among Lebanese poultry and poultry-exposed individuals from March to June 2017. This was performed by adapting a One Health approach jointly between involved governmental institutions and nongovernmental research entities.

\section{Methods}

One thousand chickens (breeders, broilers and layers) were randomly sampled (cloacal and oropharyngeal swabs for each) from poultry production sectors from 7 Lebanese governorates: North $(\mathrm{n}=200), \operatorname{Akkar}(\mathrm{n}=200)$, South ( $\mathrm{n}=150)$, Nabatiyeh $(\mathrm{n}=50)$, Mount Lebanon ( $\mathrm{n}$ $=150)$, Baalbek $(\mathrm{n}=100)$, and Beqaa $(\mathrm{n}=200)$ depending on poultry density, from March to June 2017. The timing was because many farms are not accessible during the winter due to weather conditions. We selected farms near the borders, farms with low biosecurity measures designed to prevent infectious diseases, and farms with high biosecurity measures (access restriction, decontamination troughs, and indoor-housing of birds). Between 5 and 30 samples were collected per farm according to the size of the farm, the number of pens per farm, and the farm's biosecurity level.

Each sample pool (cloacal and oropharyngeal swabs) was used to inoculate 10-day-old specific-pathogenfree embryonated chicken eggs that were incubated at $37^{\circ} \mathrm{C}$ for 30 hours. The allantoic fluid was harvested and tested for HA. Viral RNA was extracted from each HA-positive allantoic fluid and subjected to reverse transcription polymerase chain reaction (RT-PCR) to amplify 244 bp of the $M$ segment of influenza A viruses according to a WHO protocol (22). Samples positive for the $M$ segment were then subjected to additional RTPCR to determine the HA and NA subtypes (23). The first-strand cDNA was synthesized using Superscript III Reverse Transcriptase (Invitrogen, Carlsbad, CA, USA) and Uni-12 primer (5'-AGCRAAAGCAGG-3'). Using a Phusion Master Mix kit (New England Biolabs, Ipswich, MA, USA), the full genomes of three isolates were amplified using universal primers (24) and then sequenced using a 96-capillary 3730xl DNA Analyzer (Applied Biosystems, Foster City, CA, USA). Sequences were assembled using SeqMan DNA Lasergene 7 software (DNASTAR, Madison, WI, USA). The HA nucleotide sequences obtained in this study are available from GenBank under accession numbers MG882007, MG882008 and MG882009. MegAlign (DNASTAR) and BioEdit 7.0 were used for multiple sequence alignment (25). MEGA 5.0 was used for phylogenetic tree construction of gene segments by applying the neighbour-joining method with Kimura's 2-parameter distance model and 1000 bootstrap replicates (26). The trees included all Lebanese H9N2 virus sequences available in the GenBank database, and closely related $\mathrm{H}_{9} \mathrm{~N}_{2}$ viruses from other middle eastern countries as shown by a BLAST search.

Summary statistics were calculated and plotted using Excel (Microsoft, Redmond, WA, USA). Proportions of positive results were calculated with a $95 \%$ confidence interval (CI).

Between March and June 2017, 69 adult (aged > 18 years), male Lebanese farm workers with direct contact with poultry (i.e., feeding, handling, and cleaning pens) who agreed to participate were enrolled from sampled farms from the 7 governorates. Blood specimens were collected. Sera were tested for antibodies against AIVs (G1-like $\mathrm{H}_{9 \mathrm{~N}} 2$ and clade 2.3.2.1 $\mathrm{H}_{5} \mathrm{~N} 1$ ) using microneutralization assay (27). Sera were tested in duplicate and were considered positive if titres were positive at $\geq 1: 10$ dilutions $(28-30)$.

The study was approved by the Institutional Review Board of the Lebanese Ministry of Health. Informed consent was obtained from all individual participants.

\section{Results}

None of the chickens at sampling sites exhibited signs of disease. None of the sampling sites were reported by the Ministry of Agriculture surveillance systems as an outbreak area. All sites reported using the $\mathrm{H}_{9} \mathrm{~N} 2$ vaccine as verified by the sampling team. Six samples were positive for influenza A viruses and were spread in various governorates as follows: 4 from South Governorate 3 from within the same farm with 12000 chickens and 1 from another farm with 10000 chickens) and 2 from North Governorate from the same farm with 20000 chickens (Figure 1). Subtyping of the 6 positive samples indicated

Figure 1 Map of Lebanon showing the location of farms positive for avian influenza

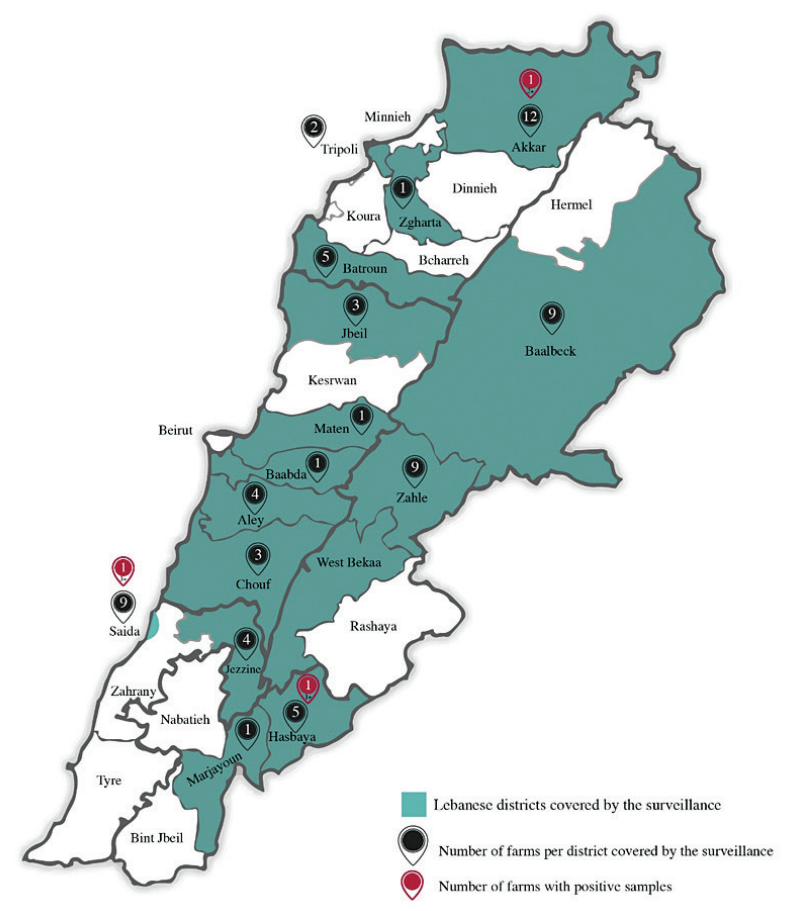


circulation of $\mathrm{H}_{9} \mathrm{~N} 2$ virus. Three of the 6 isolates were subjected to sequencing; 1 from each of the positive farms. None of the human sera tested positive for antibodies against $\mathrm{H}_{9} \mathrm{~N} 2$ or $\mathrm{H}_{5} \mathrm{~N} 1$.

Three H9N2 subtype influenza viruses were isolated from 3 chickens and were named $\mathrm{A} /$ chicken/ Lebanon/61/2017, A/chicken/Lebanon/182/2017 and A/ chicken/Lebanon/503/2017. Analysis of the HA genes showed that the nucleotide sequence similarities among the detected strains ranged from 97 to $99 \%$. In addition, alignment analysis showed that the 3 isolates were related to A/chicken/Israel/1167/2010(H9N2) (nucleotide homology 96-97\%). Based on phylogenetic analysis, the Lebanese $\mathrm{H} 9 \mathrm{~N} 2$ viruses clustered tightly with those of Israeli origin as well as Lebanese H9N2 viruses from 2010, and were related to G1-like viruses (Figure 2, available online).

\section{Discussion}

As a result of the zoonotic potential of poultry AIV, this study required a One Health approach that studied animal and human health simultaneously, and a collaborative effort between public health, animal health and private sectors. It came as a follow-up to the response to the $\mathrm{H}_{5} \mathrm{~N} 1$ outbreak reported in Lebanon in 2016 (31). Furthermore, Lebanon completed the joint external evaluation for international health regulations core capacities and AI was declared as one of the top zoonotic disease priorities for the country (32).

Our phylogenetic analysis showed that the Lebanese $\mathrm{H} 9 \mathrm{~N} 2$ viruses were closely related to $\mathrm{H} 9 \mathrm{~N} 2$ viruses from neighbouring middle eastern countries. In Lebanon, $\mathrm{H} 9 \mathrm{~N} 2$ has been detected since 2006. The viruses sequenced for this study indicated a close relationship with Lebanese viruses from 2010, suggesting that $\mathrm{H}_{9} \mathrm{~N} 2$ viruses are enzootic in Lebanon and that genetic drift, and potentially antigenic shift, is occurring.

The presence of H9N2 infection in Lebanese poultry despite the use of vaccine su ggests that the protection induced by AI vaccines is limited by the continuous antigenic changes of the viruses. This may result in influenza viruses causing outbreaks occasionally.

No antibodies against $\mathrm{H}_{9} \mathrm{~N}_{2}$ or $\mathrm{H}_{5} \mathrm{~N} 1$ AIV were detected in the poultry-exposed individuals. However, this does not mean that exposed humans are not at risk of infection, especially given that this study was crosssectional, and hence provides a slim chance to detect human infection.

The detection of $\mathrm{H}_{9} \mathrm{~N} 2$ and the $\mathrm{H}_{5} \mathrm{~N} 1$ outbreaks of 2016 highlight the fact that AI is an important zoonotic disease of concern to Lebanon. These results can aid Lebanon's preparedness to prevent, detect and respond to AI.

Our study had some limitations. Sampling was performed over the spring months, which may have led to underestimating the incidence of AI among poultry, as AI infections are more frequent over the winter months. Furthermore, our findings may have been affected by bias in relation to the sampling schemes and sample sizes used for both poultry and humans. If sampling or seasonality biases occurred, the findings would likely be an underestimation of the burden of $\mathrm{AI}$ in humans and animals in Lebanon.

\section{Conclusion}

Regular active surveillance at the human-animal interface and characterization of circulating influenza viruses in farmed poultry is highly recommended to monitor the evolution of the genetic and antigenic characteristics of influenza viruses. The One Health approach should be adapted and involvement of multisectoral governmental and nongovernmental institutions is required. Public health, animal health, and other involved sectors should establish joint formal surveillance and response mechanisms to deal with AIV threats. Such programmes allow early detection of the virulent strains and obtain more information on their virulence and antigenic properties.

\section{Acknowledgment}

The authors gratefully acknowledge assistance provided by engineer Omar Zoubeir, Dr. Moustapha Farran, engineer Omar Bahlawan and graphic designer Rony Moubarak.

Funding: This study was funded by Human Link internal grant; NIAID contract number HHSN272201400006C.

Competing interests: None declared.

\section{Surveillance de la grippe aviaire à l'interface homme-animal au Liban, 2017 Résumé}

Contexte : Les virus de la grippe aviaire causent des maladies graves chez les volailles et l'homme. Au Liban, le virus de la grippe aviaire H9N2 a été détecté en 2006 et 2010, et le sous-type H5N1, en 2016.

Objectifs : Examiner les virus de la grippe aviaire circulant actuellement au Liban à l'interface homme-animal.

Méthodes : Au total, 1000 prélèvements par écouvillonnage ont été effectués sur des volailles provenant de sept gouvernorats libanais de mars à juin 2017. Les prélèvements ont été soumis au dépistage de la grippe. Les sous-types hémagglutinine et neuraminidase des virus de la grippe aviaire ont été déterminés pour les échantillons positifs. Les segments des gènes ont été clonés et séquencés. Un prélèvement de sang a été réalisé sur 69 personnes exposées. Des 
études sérologiques ont été effectuées pour tester les sérums à la recherche d'anticorps contre le virus de la grippe aviaire.

Résultats : Chez les poulets, les résultats du test de recherche du virus de la grippe aviaire H9N2 étaient positifs pour $0,6 \%$. Les séquences obtenues se regroupaient étroitement avec celles d'origine israélienne et avec les virus H9N2 libanais de 2010. Les résultats étaient négatifs pour tous les échantillons humains.

Conclusion : Nous recommandons une surveillance régulière des virus de la grippe aviaire chez les volailles à l'aide d'une approche «Une seule santé ».

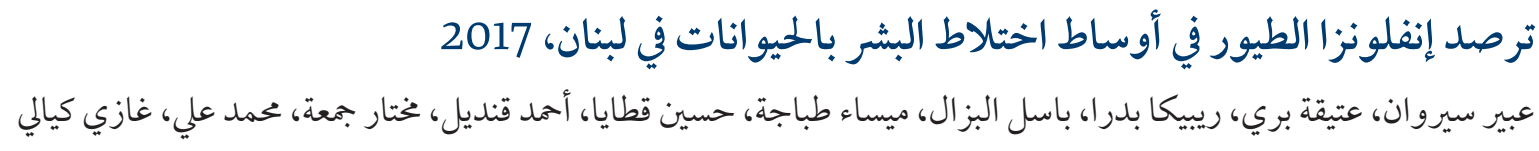

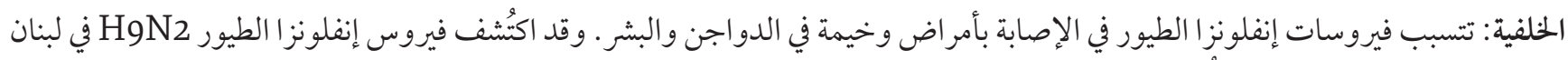

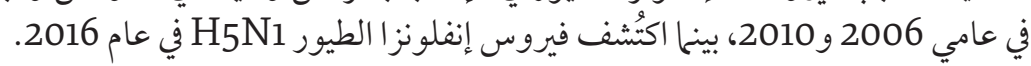

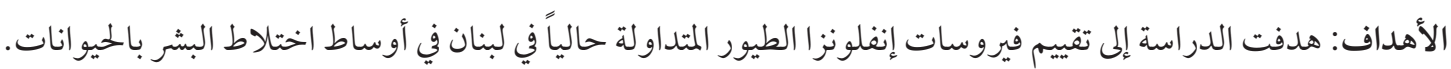

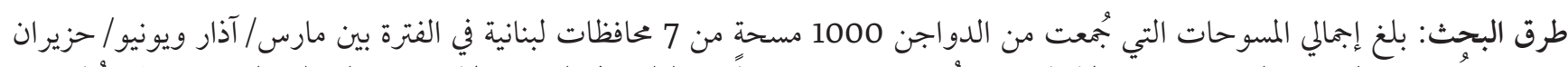

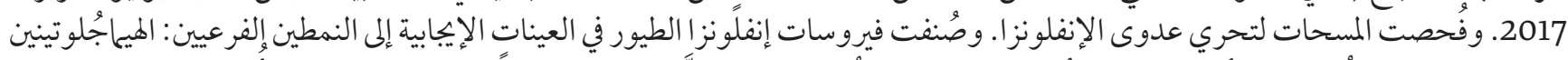

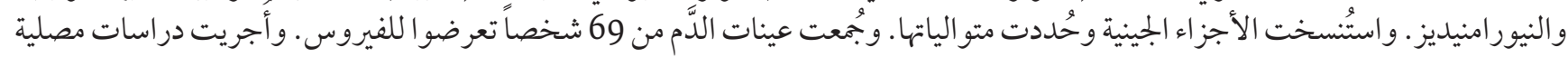

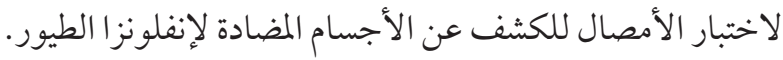

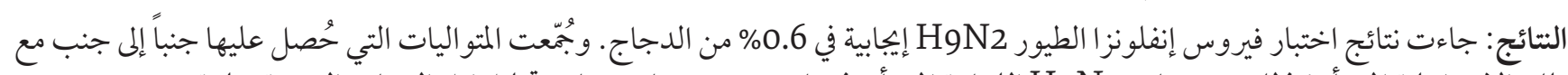

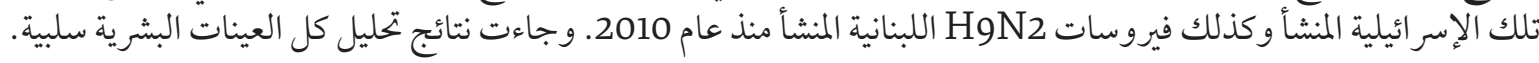

$$
\begin{aligned}
& \text { الاستنتاج: نوصي بترصد فيروسات إنفلونزا الطيور في الدواجن بصفة منتظمة باستخدام نهج الصحة الو احدة. }
\end{aligned}
$$

\section{References}

1. Capua I, Alexander DJ. Avian influenza infections in birds - a moving target. Influenza Other Respir Viruses. 2007 Jan;1(1):11-8. http://dx.doi.org/10.1111/j.1750-2659.2006.00004.x PMID:19459279

2. Lamb RA. Deadly H7N9 influenza virus: a pandemic in the making or a warning lesson? Am J Respir Crit Care Med. 2013 Jul 1;188(1):1-2. http://dx.doi.org/10.1164/rccm.201305-0914ED PMID:23815712

3. Webby RJ, Webster RG, Richt JA. Influenza viruses in animal wildlife populations. Curr Top Microbiol Immunol. 2007;315:67-83. http://dx.doi.org/10.1007/978-3-540-70962-6_4 PMID:17848061

4. Capua I, Alexander DJ. Avian influenza infection in birds: a challenge and opportunity for the poultry veterinarian. Poultry Sci. 2009 Apr;88(4):842-6. http://dx.doi.org/10.3382/ps.2008-00289 PMID:19276432

5. Webster RG, Bean WJ, Gorman OT, Chambers TM, Kawaoka Y. Evolution and ecology of influenza A viruses. Microbiol Rev. 1992 Mar;56(1):152-79. PMID:1579108

6. Vandegrift KJ, Sokolow SH, Daszak P, Kilpatrick AM. Ecology of avian influenza viruses in a changing world. Ann N Y Acad Sci. 2010 May;1195:113-28. http://dx.doi.org/10.1111/j.1749-6632.2010.05451.x PMID:20536820

7. Alexander DJ, Brown IH. History of highly pathogenic avian influenza. Rev Sci Tech. 2009 Apr;28(1):19-38. http://dx.doi. org/10.20506/rst.28.1.1856 PMID:19618616

8. Cumulative number of confirmed human cases for avian influenza A(H5N1) reported to WHO, 2003-2015 [website]. World Health Organization; 2015 (http://www.who.int/influenza/human_animal_interface/EN_GIP_20150106CumulativeNumberH5N1cases_corrected.pdf?ua=1, accessed 10 January 2020).

9. Puzelli S, Rossini G, Facchini M, Vaccari G, Di Trani L, Di Martino A, et al. Human infection with highly pathogenic A(H7N7) avian influenza virus, Italy, 2013. Emerg Infect Dis. 2014 Oct;20(10):1745-9. http://dx.doi.org/10.3201/eid2010.140512 PMID:25271444

10. Zhang T, Bi Y, Tian H, Li X, Liu D, Wu Y, et al. Human infection with influenza virus A(H1oN8) from live poultry markets, China, 2014. Emerg Infect Dis. 2014 Dec;20(12):2076-9. http://dx.doi.org/10.3201/eid2012.140911 PMID:25425075

11. Li Q, Zhou L, Zhou M, Chen Z, Li F, Wu H, et al. Epidemiology of human infections with avian influenza A(H7N9) virus in China. N Engl J Med. 2014 Jul;370(6):520-32. http://dx.doi.org/10.1017/So95026881400257X PMID:25286879

12. Tweed SA, Skowronski DM, David ST, Larder A, Petric M, Lees W, et al. Human illness from avian influenza H7N3, British Columbia. Emerg Infect Dis. 2004 Dec;10(12):2196-9. PMID:15663860 
13. Peiris M, Yuen KY, Leung CW, Chan KH, Ip PL, Lai RW, et al. Human infection with influenza H9N2. Lancet. 1999 Sep 11;354(9182):916-7. http://dx.doi.org/10.1016/s0140-6736(99)03311-5 PMID:10489954

14. Watanabe T, Zhong G, Russell CA, Nakajima N, Hatta M, Hanson A, et al. Circulating avian influenza viruses closely related to the 1918 virus have pandemic potential. Cell Host Microbe. 2014 Jun 11;15(6):692-705. http://dx.doi.org/10.1016/j.chom.2014.05.006 PMID:24922572

15. Thongratsakul S, Suzuki Y, Hiramatsu H, Sakpuaram T, Sirinarumitr T, Poolkhet C, et al. Avian and human influenza A virus receptors in trachea and lung of animals. Asian Pac J Allergy Immunol. 2010 Dec;28(4):294-301. PMID:21337915

16. Shaib HA, Cochet N, Ribeiro T, Abdel Nour AM, Nemer G, Azhar E, et al. Passaging impact of H9N2 avian influenza virus in hamsters on its pathogenicity and genetic variability. J Infect Dev Ctries. 2014 May 14;8(5):570-80. http://dx.doi.org/10.3855/jidc.4023 PMID:24820460

17. Banet-Noach C, Panshin A, Golender N, Simanov L, Rozenblut E, Pokamunski S, et al. Genetic analysis of nonstructural genes (NS1 and NS2) of H9N2 and H5N1 viruses recently isolated in Israel. Virus Genes. 2007 Apr;34(2):157-68. http://dx.doi. org/10.1007/s11262-006-0057-9 PMID:17171546

18. Cumulative number of confirmed human cases for avian influenza A(H5N1) reported to WHO, 2003-2018 [website]. World Health Organization; 2018 (http://www.who.int/influenza/human_animal_interface/2018_07_20_tableH5N1.pdf?ua=1, accessed 10 January 2020).

19. Kayali G, Barbour E, Dbaibo G, Tabet C, Saade M, Shaib HA, et al. Evidence of infection with H4 and H11 avian influenza viruses among Lebanese chicken growers. PLoS One. 2011;6(10):e26818. http://dx.doi.org/10.1371/journal.pone.0026818 PMID:22046370

20. Ibrahim E, Sirawan A, El-Bazzal B, El Hage J, Abi Said M, Zaraket H, et al. Complete genome sequence of the first $\mathrm{H}_{5} \mathrm{~N} 1$ avian influenza virus isolated from chickens in Lebanon in 2016. Genome announcements. 2016;4(5). http://dx.doi.org/10.1128/genomeA.01062-16 PMID:27795243

21. Babamahmoodi F, Davoodi AR, Ghasemian R, Delavarian L. Report of two rare complications of pandemic influenza A (H1N1). J Infect Dev Ctries. 2012 Feb 13;6(2):204-7. http://dx.doi.org/10.3855/jidc.1723 PMID:22337853

22. WHO information for laboratory diagnosis of pandemic (H1N1) 2009 virus in humans - revised [website]. World Health Organ ization; 2009 (https://www.who.int/csr/resources/publications/swineflu/WHO_Diagnostic_RecommendationsH1N1_20090521. pdf?ua =1, accessed 9 January 2020).

23. WHO manual on animal influenza diagnosis and surveillance. Geneva: World Health Organization; 2002. (https://www.who.int/ csr/resources/publications/influenza/whocdscsrncs20025rev.pdf, accessed 10 January 2020).

24. Hoffmann E, Stech J, Guan Y, Webster RG, Perez DR. Universal primer set for the full-length amplification of all influenza A viruses. Arch Virol. 2001 Dec;146(12):2275-89. http://dx.doi.org/10.1007/s007050170002 PMID:11811679 